\title{
NOTES
}

\section{Synthesis and Antitumor Activity of Polymeric Drugs Containing 5-Fluorouracil in the Main Chain}

\author{
Jun LIAO and Renxi ZHUO* \\ Chemistry Department, Wuhan University, Wuhan, \\ 430072, People's Republic of China
}

(Received September 27, 1990)

KEY WORDS Polymeric Drugs / Antitumor Activity / 5-Fluorouracil /

5-Fluorouracil (5-FU) has been used for a long time as an antitumor agent. But it has strong toxic side effects. It is expected that the introduction of 5-FU into a macromolecule can reduce the side effects and has a prolonged duration of activity. Many works were reported on the polymeric drug containing 5-FU as the pendant group. ${ }^{1-5}$ As an alternative way, we have reported a series of new polymeric drugs in which 5-FU was linked via $\mathrm{C}-\mathrm{N}$ bond. ${ }^{6}$ These systems are capable of releasing 5-FU derivatives under mild condition. This paper deals with the synthesis, hydrolysis and antitumor activity of the polymeric drugs containing 5-FU linked via carbonyl groups in the main chain. The synthetic scheme is as follows:<smiles>CCOc1nc(OC)ncc1F</smiles>

(I)

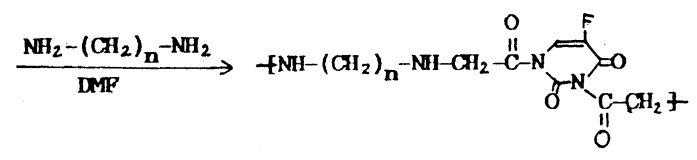

(IIIa-e)

\footnotetext{
* To whom correspondence should be addressed.
}

\section{EXPERIMENTAL}

\section{Synthesis}

1,3-Bis(bromoacetyl)-5-fluorouracil (II) Bromoacetyl bromide $(29.6 \mathrm{~g}, 0.146 \mathrm{~mol})$ in $20 \mathrm{ml}$ of acetonitrile was added dropwise into 2,4-bis(trimethylsilyl)-5-fluorouracil (I) (20.0 g, $0.073 \mathrm{~mol})^{7}$ in $100 \mathrm{ml}$ acetonitrile. Stirred at room temperature for 3.5 hour, acetonitrile was distilled off under reduced pressure. The oily residue was washed with $n$-hexane for 2 times $(50 \mathrm{ml} \times 2)$ and recrystallized from benzene. Colorless needle crystals were obtained. Yield $18.0 \mathrm{~g}(98.4 \%), \mathrm{mp} 88-89^{\circ} \mathrm{C}$. $\mathrm{C}_{8} \mathrm{H}_{5} \mathrm{O}_{4} \mathrm{~N}_{2} \mathrm{Br}_{2} \mathrm{~F}$, Found: C 26.05, H 1.51. N 7.43. Calcd for: $\mathrm{C} 25.81, \mathrm{H} 1.34, \mathrm{~N} 7.53$ IR (KBr): $1723,1703,1671 \mathrm{~cm}^{-1} \quad(\mathrm{C}=\mathrm{O})$, $1247 \mathrm{~cm}^{-1}$ (C-F). ${ }^{1} \mathrm{H}$ NMR (60 MHz, DMSO$\left.\mathrm{d}_{6}\right): \delta 4.52 \mathrm{ppm}\left(\mathrm{s}, 2 \mathrm{H}, 2 \mathrm{~N}^{1}-\stackrel{\mathrm{O}}{\mathrm{C}}-\mathrm{CH}_{2}-\right), 4.82$ $\operatorname{ppm}\left(\mathrm{s}, 2 \mathrm{H}, 2 \mathrm{~N}^{3}-\stackrel{\mathrm{O}}{\mathrm{C}}-\mathrm{CH}_{2}-\right), 8.32-8.42(\mathrm{~d}, 1 \mathrm{H}$, 6-H of pyrimidine ring). UV (Ethanol): $\lambda_{\max }$ $220.6 \mathrm{~nm}(\varepsilon=4100), 263.5 \mathrm{~nm}(\varepsilon=6800)$. MS: $m / e 372\left(\mathrm{M}^{+}\right)$.

Poly[ethylene diamino 1,3-bis(methyl carbon$y l$ )-5-fluorouracil]. (IIIa) To a mixture of II $(37.2 \mathrm{~g}, 0.01 \mathrm{~mol})$ and $\mathrm{NaHCO}_{3}(1.68 \mathrm{~g}, 0.02$ $\mathrm{mol})$ in $30 \mathrm{ml} \mathrm{DMF}$, ethylene diamine $(0.60 \mathrm{~g}$, 
Table I. Experimental data the polymers (IIIa-e)

\begin{tabular}{|c|c|c|c|c|c|c|c|c|}
\hline \multirow{3}{*}{ Polymers } & \multirow{3}{*}{$\frac{\text { Yield }}{\%}$} & \multirow{3}{*}{$\bar{M}_{n}^{\mathrm{a}}$} & \multicolumn{6}{|c|}{ Elemental Anal./\% } \\
\hline & & & \multicolumn{3}{|c|}{ Found } & \multicolumn{3}{|c|}{ Calcd $^{\mathrm{b}}$} \\
\hline & & & $\mathrm{C}$ & $\mathrm{N}$ & $\mathrm{H}$ & $\mathrm{C}$ & $\mathrm{N}$ & $\mathrm{H}$ \\
\hline IIIa & 74.1 & 2270 & 38.87 & 18.64 & 5.20 & 39.21 & 18.30 & 4.90 \\
\hline IIIb & 88.0 & 2230 & 41.49 & 17.82 & 5.74 & 41.25 & 17.50 & 5.31 \\
\hline IIIc & 83.8 & 2150 & 43.33 & 17.05 & 5.91 & 43.11 & 16.77 & 5.69 \\
\hline IIId & 80.1 & 1850 & 45.13 & 16.38 & 6.32 & 44.83 & 16.09 & 6.03 \\
\hline IIIe & 61.3 & 1860 & 46.62 & 15.78 & 6.67 & 46.41 & 15.47 & 6.35 \\
\hline
\end{tabular}

${ }^{\text {a }}$ Determined by vapour phase osmometry $\left(\mathrm{MeOH}, 45^{\circ} \mathrm{C}\right)$.

b Calculated from $-\mathrm{NH}-\left(\mathrm{CH}_{2}\right)_{n}-\mathrm{NH}-\mathrm{CH}_{2}-\mathrm{CH}_{\mathrm{O}}$

Table II. Antitumor activity of polymeric drugs (IIIa-e) tested against EAC in vitro ${ }^{\mathrm{a}}$

\begin{tabular}{|c|c|c|c|}
\hline \multirow{2}{*}{$\begin{array}{l}\text { Compounds } \\
\text { and polymers }\end{array}$} & \multicolumn{3}{|c|}{$\begin{array}{l}\text { Inhibition ratio/\% } \\
\text { Dose } / \mu \mathrm{g} \mathrm{ml}^{-1}\end{array}$} \\
\hline & 1000 & 100 & 10 \\
\hline IIIa & 47.1 & 41.7 & 35.2 \\
\hline IIIb & 55.7 & 40.5 & 26.5 \\
\hline IIIc & 23.4 & 44.5 & 26.7 \\
\hline IIId & 44.4 & 39.0 & 32.9 \\
\hline IIIe & 31.7 & 35.8 & 40.4 \\
\hline 5-FU & 62.4 & 26.8 & 7.4 \\
\hline
\end{tabular}

a Tumor cell concentration: $1-4 \times 10^{4}$ cells ml $^{-1}$; Blank test: $1 \% \mathrm{NaCl}$ aqueous solution; $4 \mathrm{~h}$.

Inhibition ratio $(\%)=$

$$
\left(1-\frac{\text { Survival cell number treated }}{\text { Survival cell number of control }}\right) \times 100
$$

$0.01 \mathrm{~mol}$ ) was added. It was allowed to stir at $70-80^{\circ} \mathrm{C}$ for $24 \mathrm{~h}$ and then filtered. The filtrate was poured with vigorously stirring into $500 \mathrm{ml}$ of acetone to precipitate the polymer. The precipitate was then dissolved in $10 \mathrm{ml}$ of $N, N^{\prime}$-dimethylformamide (DMF). Reprecipitation from $200 \mathrm{ml}$ of acetone to give the product (IIIa), $2.0 \mathrm{~g}$, yield $74.1 \%$.

Polymers (IIIb-e) were synthesized with the same method as for IIIa and the results were shown in Table I.

\section{Hydrolysis of the Polymers}

The hydrolysis of polymers were investigated in vitro at $37^{\circ} \mathrm{C}$ under shaking in various kinds of aq solutions. At a given time, the polymers and their hydrolyzates in $0.3 \mathrm{ml}$ of the mixture were separated with TLC method (kiesel gel GF254 (Merck), eluent; acetone: ethyl ether $=8: 2$ ). The hydrolyzate (5FU) was dissolved in $10 \mathrm{ml}$ of $0.1 \mathrm{moll}^{-1}$ $\mathrm{NaOH}$ aq solution, and the amount of $5 \mathrm{FU}$ released was determined by using UV spectrum method (5100 of $\varepsilon_{283}$ for $5 F U$ anion in $0.1 \mathrm{moll}^{-1} \mathrm{NaOH}$ aq soln.).

\section{Measurement of Antitumor Activity}

The antitumor activity of the polymers (IIIa- e) were tested against Ehrlich ascites carcinoma (EAC) both in vitro and in vivo according to the typical NCI protocol. The results were shown in Tables II and III.

\section{RESULTS AND DISCUSSION}

Synthesis and Characterization of the Compound (II) and Polymers (IIIa- e)

In our previous paper, ${ }^{6}$-FU was ever introduced via $\mathrm{C}-\mathrm{N}$ bond into the main chain of polymers. These polymeric drugs could be hydrolyzed under mild conditions in aqueous 
Synthesis and Antitumor Activity of Polymeric Drugs Containing 5-Fluorouracil in the Main Chain

Table III. Antitumor activity of the polymeric drugs (IIIa- e) tested against EAC in vivo ${ }^{\mathbf{a}}$

\begin{tabular}{|c|c|c|c|c|c|c|c|}
\hline \multirow{2}{*}{$\begin{array}{c}\text { Polymeric } \\
\text { drugs } \\
\text { No. }\end{array}$} & \multirow{2}{*}{$\frac{\text { Dose }}{\mathrm{mg} \mathrm{kg}^{-1}}$} & \multirow{2}{*}{$\begin{array}{c}\text { Route } \\
\text { of } \\
\text { Admin. }\end{array}$} & \multicolumn{2}{|c|}{$\begin{array}{l}\text { No. of mice in } \\
\text { treatment }\end{array}$} & \multicolumn{2}{|c|}{$\begin{array}{c}\text { Average weight } \\
\text { of tumor/g }\end{array}$} & \multirow{2}{*}{$\begin{array}{c}\begin{array}{c}\text { Inhibition } \\
\text { ratio }\end{array} \\
\% \%\end{array}$} \\
\hline & & & Start & End & Control & Treated & \\
\hline \multirow[t]{3}{*}{ IIIa } & 65 & s.c 10 & 10 & 10 & 1.214 & 1.010 & 16.8 \\
\hline & 130 & s.c 9 & 10 & 10 & 1.214 & 0.880 & 27.5 \\
\hline & 390 & s.c 9 & 10 & 8 & 1.214 & 0.765 & 37.0 \\
\hline \multirow[t]{3}{*}{ IIIlb } & 90 & s.c 9 & 10 & 9 & 1.214 & 1.226 & \\
\hline & 180 & s.c 9 & 10 & 9 & 1.214 & 0.920 & 24.2 \\
\hline & 540 & s.c 9 & 10 & 8 & 1.214 & 0.611 & 49.7 \\
\hline \multirow[t]{3}{*}{ IIIc } & 60 & s.c 10 & 10 & 9 & 1.214 & 0.703 & 42.1 \\
\hline & 120 & s.c 10 & 10 & 9 & 1.214 & 0.617 & 49.2 \\
\hline & 360 & s.c 10 & 10 & 4 & 1.214 & 0.918 & 24.4 \\
\hline \multirow[t]{3}{*}{ IIId } & 75 & s.c 10 & 10 & 10 & 1.214 & 0.623 & 48.7 \\
\hline & 150 & s.c 10 & 10 & 10 & 1.214 & 0.615 & 50.7 \\
\hline & 200 & s.c 10 & 10 & 10 & 1.214 & 0.887 & 26.9 \\
\hline \multirow[t]{3}{*}{ IIIe } & 100 & s.c 10 & 10 & 10 & 1.214 & 0.863 & 28.9 \\
\hline & 200 & s.c 10 & 10 & 9 & 1.214 & 0.793 & 34.6 \\
\hline & 400 & s.c 10 & 10 & 8 & 1.214 & 0.941 & 26.2 \\
\hline $5-\mathrm{FU}$ & 20 & s.c 10 & 10 & 8 & 1.214 & 0.512 & 58.0 \\
\hline
\end{tabular}

a $P$ value $<0.05$.

$$
\text { Inhibition ratio }(\%)=\left(1-\frac{\text { Average tumor wt in treated mice }}{\text { Average tumor wt in control mice }}\right) \times 100
$$

solution. However, the hydrolyzate was 5-FU derivatives, but was not 5-FU itself. When 5-FU was linked directly via carbonyl group in the main chain, this kind of polymeric drugs can release 5-FU in the hydrolysis. To obtain the polymeric drugs, compound (II) was synthesized with the reaction of 2,4-bis(trimethylsilyl)-5-fluorouracil and two equivalents of bromoacetyl bromide. When they reacted in equal mole ratio, 1-bromoacetyl-5-fluorouracil (IV) was the main product. (mp $141-142^{\circ} \mathrm{C}$ ). By the condensation of compound (II) with a series of $\alpha, \omega$-diamines in the presence of sodium bicarbonate, polymeric drugs in which 5-FU was linked via carbonyl group were prepared. All the compound and polymers were structur-<smiles>O=C(CBr)n1cc(F)c(=O)[nH]c1=O</smiles>

(IV)

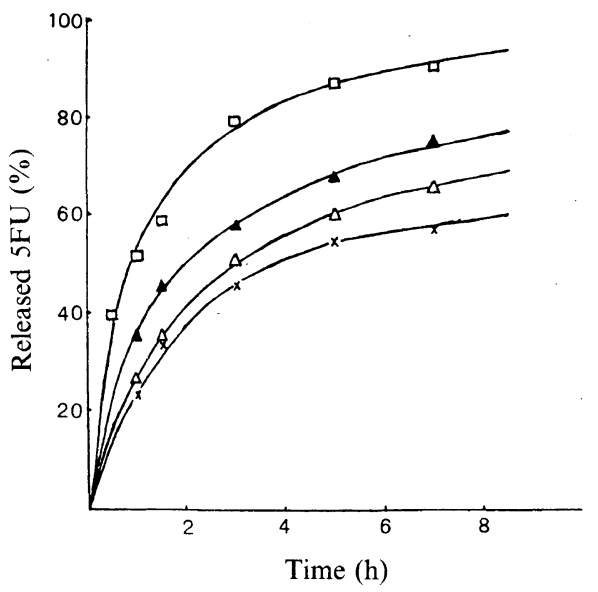

Figure 1. Release rate of 5-FU from polymer IIIb in $0.1 \mathrm{moll}^{-1} \mathrm{NaOH}(\square), 0.1 \mathrm{M}$ phosphate buffer $(\boldsymbol{\Delta})$, $0.1 \mathrm{moll}^{-1} \mathrm{HCl}(\times)$ and polymer IIIe in $0.1 \mathrm{M}$ phosphate buffer $(\triangle)$.

ally confirmed by ${ }^{1} \mathrm{H}$ NMR, IR and UV spectra as well as elemental analysis. These newly prepared polymeric drugs are water-soluble. 
Hydrolysis of the Polymers

In order to evaluate the release behavior of $5 \mathrm{FU}$ in vivo, the hydrolysis of the polymers was carried out using the method described above. The results were shown in Figure 1. The order of hydrolysis of polymer (IIIb) was as follows: $0.1 \mathrm{moll}^{-1} \mathrm{NaOH}$ aq soln. $>0.1 \mathrm{M}$ phosphate buffer soln. $>0.1 \mathrm{moll}^{-1} \mathrm{HCl}$ aq soln. When hydrolyzed in $0.1 \mathrm{M}$ phosphate buffer, the release rate of polymer (IIIe) was slower than that of polymer (IIIb). It can be concluded that hydrophilicity has significant effects on the release rate of the polymeric drugs.

Antitumor Activity of Polymeric Drugs (IIIa- e)

As shown in Tables II (in vitro) and III (in vivo), all the polymeric drugs exhibited significant antitumor activity, although lower than that for free 5-FU. The doses of administration have a marked influence on the inhibition ratio. For polymers (IIIc-e), when the dose increased over a definite value respectively, the inhibition ratio decreased, on the contrary. This phenomenon was also observed by Ning and his coworkers. ${ }^{8}$

Acknowledgment. The authors are indebted to Mr. Zheng Fanbo of Tongji Medical University (Wuhan, China) for carrying out the tests of antitumor activity.

\section{REFERENCES}

1. C. G. Gebelein, W. Baig, R. M. Morgan, and R. Glovwacky, Polym. Prepr., 20, 600 (1979).

2. T. Ouchi, H. Yuyama, and O. Vogl, Makromol. Chem., Rapid Commun., 6, 815 (1985).

3. T. Ouchi, K. Hagita, M. Kawashima, and T. Inoi, J. Bioact. Compat. Polym., 3, 53 (1988).

4. R. X. Zhuo, J. Liao, and C. L. Fan, Chem. J. Chin. Univ. (Eng.), 6(3), 244 (1990).

5. F. S. Young and R. X. Zhuo, Polym. J., 22, 592 (1990).

6. R. X. Zhuo, Preprints, Symposium on Polymers, (Chengdu, China, Nov. 14-18, 1989), Part 1, p 18.

7. R. Duschinsky and T. F. Gabriel, US Patent, 3,354,160 (1967).

8. N. S. Ning, H. Sun, and Y. Wang, Proceedings of the National III Symposium of Experiment and Research of Immunodeficient Animals, Shanghai, China, November 1990, p 108. 